\title{
ANTERIOR ISCHEMIC OPTIC NEUROPATHY FOLLOWING NECK DISSECTION
}

\author{
Scott E. Strome, MD, ${ }^{1}$ Jimmy S. Hill, MD, ${ }^{1}$ Michael A. Burnstine, $M{ }^{2}{ }^{2}$ \\ Jill Beck, MD, ${ }^{1}$ Douglas B. Chepeha, MD, ${ }^{1}$ Ramon M. Esclamado, MD $^{3}$ \\ ${ }^{1}$ Department of Otolaryngology-Head and Neck Surgery, University of Michigan Medical Center, 1500 E. \\ Medical Center Dr., Ann Arbor, Michigan 48109 \\ ${ }^{2}$ Department of Ophthalmology, W.K. Kellogg Eye Center, University of Michigan, Ann Arbor, Michigan \\ ${ }^{3}$ Department of Otolaryngology-Head and Neck Surgery, Cleveland Clinic Foundation, Cleveland, Ohio
}

Received 8 December 1995; accepted 5 June 1996

\begin{abstract}
Background: Ischemic optic neuropathy (ION) is a rare but devastating complication of surgery. It has traditionally been associated with intraoperative hypotension in patients with underlying arteriosclerosis.

Methods: We present a case of ION following bilateral neck dissections in which there was minimal intraoperative hypotension and preservation of both internal jugular veins. The potential etiology of this disease is discussed along with a review of the literature.

Results: Five cases of ION following neck dissection have been documented. This complication is associated with the combination of intraoperative hypotension and anemia in the setting of prolonged bilateral neck dissection. Treatment is supportive, and final visual prognosis is variable.

Conclusions: Ischemic optic neuropathy following neck dissection is best avoided by intraoperative blood pressure and anemia management. When it does occur, supportive therapy must be given. Final visual outcome is variable. (C) 1997 John Wiley \& Sons, Inc. Head Neck 19: 148-152, 1997.
\end{abstract}

Keywords: optic neuropathy; neck dissection; hypotension; anemia

Anterior ischemic optic neuropathy (AION), or

Correspondence to: Dr. Strome

CCC 0148-6403/97/020148-05

(C) 1997 John Wiley \& Sons, Inc. optic nerve infarction, usually occurs as an acute, painless, spontaneous vision loss event in middle-aged and elderly individuals. ${ }^{1}$ It has also been reported after many nonopthalmologic surgical procedures. ${ }^{2}$ Intraoperative factors associated with acute visual loss include anemia, hypotension, blood loss, arteriosclerosis, and increased intraocular pressure. In the head and neck literature, ischemic optic neuropathy (ION) has been reported after radical neck dissection with bilateral ligation of the jugular veins, either as a staged or simultaneous procedure..$^{3-7}$

All of these patients were reported to have clinical manifestations of venous congestion with severe facial edema and chemosis; it was suggested that the pathophysiology was, in part, due to venous hypertension. However, all of these cases were also noted to have significant blood loss and/or episodes of hypotension, a more likely cause for the optic nerve damage. Detailed histopathologic examination revealing optic nerve infarctions has illustrated the importance of hypotension and anemia. ${ }^{5,7,8} \mathrm{We}$ describe the first case of AION after bilateral neck dissections sparing both jugular veins in a patient undergoing resection of squamous cell carcinoma of the left mandibular alveolus. Unlike previously reported 
cases, this patient did not undergo central venous ligation, suggesting that other medical and anesthetic factors caused this patient's visual loss.

\section{CASE REPORT}

In July 1995, a 60-year-old man was referred to the University of Michigan Medical Center for evaluation of a 2-month history of pain in the left mandibular alveolus following tooth extraction. Past medical and surgical histories were unremarkable except for the detection of type II diabetes mellitus during the course of the patient's hospitalization. Past ocular history was notable for hand motion vision in the right eye secondary to a dense cataract and cataract extraction with intraocular lens implantation in the left eye. The patient had a 50-pack-year smoking history and a 20-year history of alcohol consumption, approximately $1 \mathrm{~L} /$ day. He denied alcohol use in the year prior to presentation.

Physical examination revealed a friable, exophytic mass involving the left hemimandible, from the retromolar trigone to a location $1 \mathrm{~cm}$ across the symphysis. The left floor of mouth and left ventral tongue were also involved. Additionally, there was a $1.5-\mathrm{cm}$ ipsilateral level I node. A biopsy of the primary site revealed squamous cell carcinoma, and the patient was staged as a T4N1M0 squamous cell carcinoma of the left mandibular alveolus.

The patient was taken to the operating room for a direct laryngoscopy, left composite resection, left modified radical neck dissection, right selective neck dissection levels I-IV with revascularized fibular osseocutaneous flap reconstruction. Both of the common facial veins were ligated during the dissection, whereas the internal jugular veins remained intact. From a surgical standpoint, the procedure was uneventful, with no intraoperative compression of the globe. Blood loss during the procedure totaled $1200 \mathrm{~mL}$. The duration of the operation was 14 hours.

Preoperative and postoperative hemoglobins were $13.5 \mathrm{mg} / \mathrm{dL}$ and $7.6 \mathrm{mg} / \mathrm{dL}$, respectively, and the patient received one unit of packed red blood cells intraoperatively. The lowest intraoperative blood pressure was $87 / 45 \mathrm{~mm} \mathrm{Hg}$ for a duration of 5 minutes. There were several episodes of mild hypotension to this level, none lasting more than 2-3 minutes. No intraoperative dysrhythmias were noted, and a circumferential neck dressing was not utilized in the postoperative period.

The patient did well in the immediate postoperative period, with no focal neurologic symp- toms. However, on the second postoperative day, when the patient became more alert, he complained of blurred vision in his left eye. Ophthalmologic evaluation revealed hand motion vision in the right eye and 20/30 vision in the left eye. He had a left relative afferent pupillary defect, constricted left visual field, and swollen left optic nerve head. No view of the right optic nerve was possible due to a dense cataract.

The patient was diagnosed with a left AION resulting from intraoperative anemia and hypotension. The possibility of bilateral optic neuropathy could not be evaluated because of the presence of a dense cataract; however, he had a left afferent pupillary defect which indicated that the left side was more severely involved. No further treatment was recommended, because the patient was transfused, and blood pressure was normalized.

The patient's vision remained stable for 1 week, then gradually improved. At 6 weeks postoperation, the patient's visual acuity in the left eye returned to its $20 / 20$ preoperative state. His hand motion vision in the right eye was unchanged and attributed to cataract.

\section{DISCUSSION}

Postoperative ION has been reported as an isolated complication of cardiac, thoracic, abdominal, orthopedic, neurosurgical, and otolaryngologic procedures., ${ }^{2,9,10}$ Five cases have been documented in the head and neck literature (Table 1). ${ }^{3-7}$ The common features of these head and neck cases were central venous congestion secondary to bilateral neck dissections with simultaneous or staged jugular vein ligation and intraoperative hypotension. We report a case of AION following bilateral neck dissection in which both jugular veins were spared.

Most injuries to the eye during nonophthalmic surgery are not severe, such as corneal abrasions. Rarer and more serious is the complication of optic nerve infarction. It is characterized by visual loss, an afferent pupillary defect, and visual field changes. Ischemic optic neuropathy has been separated into posterior optic neuropathy and anterior optic neuropathy based upon anatomic blood supply and different clinical pictures.

Posterior ischemic optic neuropathy (PION), the rarest ION, presents as acute visual loss with visual field defects without optic nerve head edema. The etiology is poorly understood but is believed to represent decreased oxygen delivery to the posterior portion of the optic nerve between 
Table 1. Cases of ischemic optic neuropathy after neck dissection.

\begin{tabular}{|c|c|c|c|c|c|c|c|}
\hline $\begin{array}{l}\text { Patient No./ } \\
\text { age/sex/ } \\
\text { reference }\end{array}$ & Procedure & $\begin{array}{l}\text { Vascular } \\
\text { risk factor }\end{array}$ & $\begin{array}{l}\text { Hypotension*/ } \\
\text { estimated } \\
\text { blood loss }\end{array}$ & Latency & $\begin{array}{l}\text { Visual acuity } \\
\text { (initial, final) }\end{array}$ & $\begin{array}{l}\text { Optic disc } \\
\text { appearance } \\
\text { (early, late) }\end{array}$ & $\begin{array}{c}\text { Other } \\
\text { documented } \\
\text { clinical } \\
\text { manifestations }\end{array}$ \\
\hline $\begin{array}{l}\text { 1/60/M } \\
\text { (present } \\
\text { case) }\end{array}$ & $\begin{array}{l}\text { R. SND (I-IV) } \\
\text { L. MRND } \\
\text { Sparing IJV } \\
\text { and CN } 11\end{array}$ & $\begin{array}{l}\text { NIDDM } \\
\text { smoking }\end{array}$ & Transient/3 U & $\begin{array}{l}2 \text { Days } \\
\text { after } \\
\text { surgery }\end{array}$ & $\begin{array}{l}\text { 20/30 OS; } \\
\text { 20/20 OS } \\
6 \text { wk }\end{array}$ & $\begin{array}{l}\text { Early edema; } \\
\text { late optic } \\
\text { pallort }\end{array}$ & None \\
\hline $2 / 64 / M^{4}$ & $\begin{array}{l}\text { Simultaneous } \\
\text { bilateral } \\
\text { radical neck } \\
\text { dissection }\end{array}$ & None & Yes/11 U & $\begin{array}{l}\text { Shortly } \\
\text { after } \\
\text { surgery }\end{array}$ & $\begin{array}{l}\text { NLP OU; } \\
\text { NLP } 4 \text { mo }\end{array}$ & $\begin{array}{c}\text { Early normal; } \\
\text { late optic } \\
\text { atrophy } \neq\end{array}$ & $\begin{array}{l}\text { Facial edema, } \\
\text { limited EOM, } \\
\text { severe } \\
\text { chemosis }\end{array}$ \\
\hline $3 / 69 / F^{3}$ & $\begin{array}{l}\text { Staged } \\
\quad \text { bilateral } \\
\text { radical neck } \\
\text { dissection } \\
(2 \text { mo.) }\end{array}$ & $\begin{array}{l}\text { Arterio- } \\
\text { sclerosis§ }\end{array}$ & Yes/5 U & $\begin{array}{l}3 \text { Days } \\
\text { after } \\
\text { surgery }\end{array}$ & $\begin{array}{l}\text { NLP OU; } \\
\text { NLP } 1 \text { mo }\end{array}$ & $\begin{array}{l}\text { Early normal; } \\
\text { late optic } \\
\text { atrophy } \neq\end{array}$ & $\begin{array}{l}\text { Facial edema, } \\
\text { chemosis, } \\
\text { proptosis, } \\
\text { normal } \\
\text { intraocular } \\
\text { pressures }\end{array}$ \\
\hline $4 / 67 / M^{5}$ & $\begin{array}{l}\text { Simultaneous } \\
\quad \text { bilateral } \\
\text { radical neck } \\
\text { dissection }\end{array}$ & NR & Yes/9 U & $\begin{array}{l}3 \text { Days } \\
\text { after } \\
\text { surgeryll }\end{array}$ & $\begin{array}{l}\text { NLP OU; } \\
\quad \text { NLP } 2 \text { wk }\end{array}$ & $\begin{array}{l}\text { Early normal; } \\
\text { late optic } \\
\text { atrophy } \neq\end{array}$ & $\begin{array}{l}\text { Facial and } \\
\quad \text { eyelid edema }\end{array}$ \\
\hline $5 / 48 / M^{6}$ & $\begin{array}{l}\text { Staged } \\
\text { bilateral } \\
\text { radical neck } \\
\text { dissection } \\
(1 \mathrm{yr})\end{array}$ & HTN & $\mathrm{NR} / 4 \mathrm{U}$ & $\begin{array}{l}\text { Shortly } \\
\text { after } \\
\text { surgery }\end{array}$ & $\begin{array}{l}\text { NLP OU; } \\
\text { NLP } 9 \text { mo }\end{array}$ & $\begin{array}{l}\text { Early pale } \\
\text { swelling of } \\
\text { optic nerve } \\
\text { OU; late } \\
\text { optic } \\
\text { atrophy† }\end{array}$ & $\begin{array}{l}\text { Facial and } \\
\text { eyelid edema, } \\
\text { increased } \\
\text { intraocular } \\
\text { pressure }\end{array}$ \\
\hline $6 / 67 / M^{7}$ & $\begin{array}{l}\text { Simultaneous } \\
\text { bilateral } \\
\text { radical neck } \\
\text { dissection }\end{array}$ & None & Yes/9 U & $\begin{array}{l}3 \text { Days } \\
\text { after } \\
\text { surgery }\end{array}$ & NLP OU & $N R \ddagger$ & $\begin{array}{l}\text { Patient } \\
\text { gradually } \\
\text { obtunded; left } \\
\text { CVA }\end{array}$ \\
\hline
\end{tabular}

$R$, right; SND, selective neck dissection; L, left; MRND, modified radical neck dissection; IJV, internal jugular vein; CN, cranial nerve; NIDDM, non-insulin dependent diabetes mellitus; OS, left eye; NLP, no light perception; OU, both eyes; EOM, extraocular motility; NR, not reported; and CVA, cerebral vascular accident.

*Hypotension defined as systolic blood pressure $<80 \mathrm{~mm} / \mathrm{Hg}$.

tAnterior ischemic optic neuropathy (AION).

$\neq$ Posterior ischemic optic neuropathy (PION).

§Finding of atheromatous plaques narrowing ophthalmic artery lumina noted at post mortem.

"Severe facial edema preventing previous eye opening.

the optic foramen at the orbital apex and the central retinal artery's point of entry. ${ }^{9}$ Postoperative PION has been reported after laparotomy, open heart surgery, hip arthroplasty, and radical neck dissection. ${ }^{2-5,9,10}$ Severe hypotension and anemia have been associated with this entity. ${ }^{7-10}$

Anterior ischemic optic neuropathy, or optic nerve head infarction, is the most common optic nerve disorder of the elderly. ${ }^{11}$ There are two types of AION: arteritic and nonarteritic. The pathophysiology of arteritic AION is well understood, consisting of occlusion of the small posterior ciliary arteries that supply the anterior optic nerve, an unlikely presentation in the postoperative state. Clinical findings of visual loss, temporal ache or tenderness, polymyalgia rheumatica, and jaw claudication with an elevated erythro- cyte sedimentation rate suggest this diagnosis. The diagnosis is confirmed by temporal artery biopsy revealing granulomatous inflammation with giant cells. Treatment with high-dose corticosteroids is effective therapy and usually prophylactic against involvement of the contralateral optic nerve.

In contrast, nonarteritic AION (NAION), the more common AION, is less well understood; the mechanism by which the anterior optic nerve head becomes edematous is unknown. Clinically, NAION usually occurs as an acute, spontaneous painless visual loss associated with pallid disc swelling in one eye in middle-aged and elderly individuals. ${ }^{1}$ Hypertension and other arteriosclerotic risk factors are often documented. In perioperative periods, anemia, blood loss, and hypo- 
tension have been implicated in postoperative visual loss. ${ }^{2,6,7,9,10}$ Although nonsurgical treatment such as corticosteroids, phenytoin sodium, norepinephrine infusion, and anticoagulants have been tried, they have been unsuccessful. ${ }^{9,10}$ Anecdotally, however, blood pressure control and transfusion have been reported to be effective. ${ }^{12}$ More recently, optic nerve sheath decompression has been shown to be ineffective and perhaps harmful in the treatment of NAION. ${ }^{1}$ Data from the Ischemic Optic Neuropathy Decompression Trial (IONDT), a prospective randomized study, revealed that $42 \%$ of patients with NAION in the nonsurgical group had at least a three-line improvement in visual function, compared with $33 \%$ in the surgical decompression group 6 months after the event. ${ }^{1}$

The diagnosis of ION should be suspected if the patient complains of visual loss during the first postoperative week, especially if it is painless and affects the visual field. The clinical presentation varies considerably and can be misleading. Ophthalmic consultation may be delayed for several reasons: patients may be sedated and intubated after surgery and unable to communicate; patients may consider altered vision to be a normal part of recovery after anesthesia; patients may be misdiagnosed with confusion or delerium; and patient's visual loss itself may lead to a confusional state. ${ }^{9}$ Cases may be bilateral, and an afferent pupillary defect may be seen if one eye is affected more relative to the fellow eye. Ischemic optic neuropathy is often associated with diabetes, hypertension, low hematocrit, and intraoperative hypotension. Fundoscopy will often reveal a swollen optic nerve head, because AION is a more common postoperative event than is PION., ${ }^{2,9}$

Early recognition of visual loss and ophthalmologic consultation is important because prognosis may vary. For instance, if the source is embolic in origin, a cardiac or carotid source should be sought and medical or surgical intervention considered. Other processes to be considered in the differential diagnosis of postoperative visual loss include cortical blindness, retinal artery occlusion, and ophthalmic venous obstruction, all diagnosed by a thorough ophthalmologic examination.

The patient described in this report underwent uncomplicated left composite resection, left modified radical neck dissection sparing the internal jugular vein, and right selective neck dissection levels I-IV with revascularized osseocu- taneous fibular flap reconstruction. The lowest intraoperative blood pressure recorded was 87/45 for a duration of 5 minutes, and blood loss totaled 1.2 L, resulting in a five-point hemoglobin drop.

This differs from previous reports of NAION in head and neck cancer patients in which central venous hypertension secondary to bilateral jugular vein ligation and intraoperative hypotension were considered the primary etiologic factors. We do not believe central venous congestion to be the etiology of ION in these cases but rather anemia and hypotension. Like Brown et al, ${ }^{10}$ we suggest maintaining the $\mathrm{Hb}$ level above $8 \mathrm{mg} / \mathrm{dL}$ and blood pressure greater than $60 \%$ of its preoperative state during surgery.

Although our patient had a long history of tobacco use and recent onset of non-insulin-dependent diabetes mellitus, there was no documented history of cardiovascular disease. This suggests that hypotension and anemia in patients undergoing lengthy ablative and reconstructive procedures for the treatment of head and neck cancers may place them at risk for ION.

\section{CONCLUSION}

Nonarteritic AION is a rare, sometimes devastating, complication of surgical procedures. We present a case of NAION after bilateral neck dissection in the setting of hypotension and anemia. The risk of NAION may be reduced by stringent intraoperative management of blood pressure and anemia. This is particularly important in an era in which the indications for blood replacement are more conservative.

We recommend maintaining $\mathrm{Hb}$ above $8 \mathrm{mg} /$ $\mathrm{dL}$ and blood pressure greater than $60 \%$ of its preoperative state. Postoperative management of NAION includes observation and risk factor modulation such as blood pressure, anemia, and hypercholesterolemia control. Optic nerve sheath fenestration has been shown to be ineffective, perhaps harmful. ${ }^{1}$ Preoperative recognition of risk factors potentially associated with this disorder and careful intraoperative patient monitoring is essential.

\section{REFERENCES}

1. The Ischemic Optic Neuropathy Decompression Trial Research Group. Optic nerve decompression surgery for nonarteritic anterior ischemic optic neuropathy (NAION) is not effective and may be harmful. JAMA 1995; 273:625-632.

2. Katz DM, Trobe JD, Cornblath WT, Kline LB. Ischemic 
optic neuropathy after lumbar spine surgery. Arch Ophthalmol 1994;112:925-931.

3. Milner GAW. A case of blindness after simultaneous bilateral neck dissection. J Laryngol 1960;74:880-885.

4. Chutkow JG, Sharbrough FW, Riley FC. Blindness following simultaneous bilateral neck dissection. Mayo Clin Proc 1973;48:713-717.

5. Marks SC, Jaques DA, Hirata RM, Saunders JR. Blindness following bilateral radical neck dissection. Head Neck 1990;12:342-345.

6. Wilson JF, Freeman SB, Breena DP. Anterior ischemic optic neuropathy causing blindness in the head and neck surgery patient. Arch Otolaryngol Head Neck Surg 1991; 117:1304-1308.

7. Nawa Y, Jacques JD, Miller NR, Palarmo RA, Green WR. Bilateral posterior optic neuropathy after bilateral radi- cal neck dissection and hypotension. Graefes Arch Clin Exp Ophthalmol 1992;230:301-308.

8. Johnson MW, Kincaid MC, Trobe JD. Bilateral retrobulbar optic nerve infarctions after blood loss and hypotension. Ophthalmology 1987;94:1577-1584.

9. Williams EL, Hart WM, Tempelhoff R. Postoperative ischemic optic neuropathy. Anesth Analg 1995;80:10181029.

10. Brown RH, Schauble JF, Miller NR. Anemia and hypotension as contributors to perioperative loss of vision. Anesthesiology 1994;80:222-226.

11. Boghen DR, Glaser JS. Ischemic optic neuropathy: the clinical profile and history. Brain 1975;98:689-708.

12. Connolly SE, Gordon KB, Horton JC. Salvage of vision after hypotension-induced ischemic optic neuropathy. Am J Ophthalmol 1994;117:235-242. 